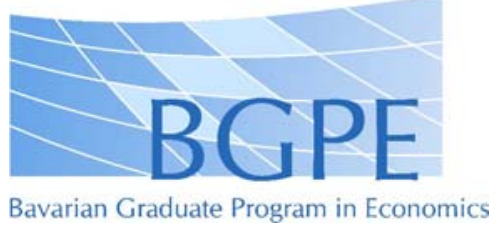

BGPE Discussion Paper

No. 37

\title{
The impact of ballot access restrictions on electoral competition: Evidence from a natural experiment
}

\author{
Marcus Drometer \\ Johannes Rincke
}

January 2008

ISSN 1863-5733

Editor: Prof. Regina T. Riphahn, Ph.D.

Friedrich-Alexander-University Erlangen-Nuremberg

(c) Marcus Drometer, Johannes Rincke 


\title{
The impact of ballot access restrictions on electoral competition: Evidence from a natural experiment
}

\author{
Marcus Drometer* Johannes Rincke ${ }^{\dagger}$ \\ Department of Economics, University of Munich
}

January 2008

\begin{abstract}
Measuring the effect of ballot access restrictions on electoral competition is complicated because the stringency of ballot access regulations cannot be treated as being exogenous to candidates' entry decisions. This paper exploits the 1968 U.S. Supreme Court decision to strike down Ohio's ballot access laws as a natural experiment to overcome the endogeneity problem. The evidence from difference-in-difference estimations suggests that the court decision and the accompanying sharp decrease in Ohio's petition requirements resulted in major parties facing a significant increase in competition from third party and independent candidates.
\end{abstract}

Keywords: Ballot access, petition requirements, electoral competition, natural experiment

JEL Classification: D72, D78

\section{Introduction}

The idea that competition is a salient prerequisite for the efficient functioning of markets is one of the central insights of economics. Consequently, the literature has thoroughly analyzed the ways in which incumbent firms

*Seminar for Economic Policy, Department of Economics, University of Munich, Akademiestr. 1/II, D-80799 Munich. Phone: +49 89 2180-2249, fax: +49 89 2180-6296, email: marcus.drometer@lrz.uni-muenchen.de

†Seminar for Economic Policy, Department of Economics, University of Munich, Akademiestr. 1/II, D-80799 Munich. Phone: +49 89 2180-6753, fax: +49 89 2180-6296, email: johannes.rincke@lrz.uni-muenchen.de 
might reduce competition, for example, by creating entry barriers to deter potential competitors. ${ }^{2}$ Recent contributions in political economics point to a similar importance of competition for political markets (e.g., see Persson and Tabellini, 2000). But in spite of a number of possible ways in which parties in power might hinder potential contestants, the empirical evidence regarding the effectiveness of restrictions to political competition is still very limited.

Our investigation looks at a specific example of entry restrictions on political markets. In particular, we estimate the effect of ballot access requirements on the degree of electoral competition in U.S. House elections as measured by the number of minor party and independent candidates. Since the stringency of ballot access regulations cannot be treated as being exogenous to candidates' entry decisions, we exploit a natural experiment to identify the effectiveness of ballot access restrictions. Our results suggest that ballot access regulations as used by most states in the U.S. significantly reduce electoral competition.

Ballot access laws specify the conditions potential candidates need to fulfill in order to be listed on the ballot. In the U.S., these restrictions greatly differ between major and minor parties. For major party candidates, the most common route to get a candidate on the ballot is a primary election. Minor parties and independent candidates, however, commonly need to file a petition signed by a certain number of eligible voters. These petition requirements can potentially be designed by the (major) parties in power in a way that serves their interests and deters competition from minor political parties and independent candidates. ${ }^{3}$ To put it practically, suppose that in some states major parties are only challenged by weak competitors, making it unnecessary to set particularly strict regulations to prevent the entry of those competitors. In other states, however, potential competitors might be strong and the parties in power will tend to choose more restrictive ballot access requirements to protect their dominant position. As a consequence, any estimates of the effectiveness of barriers to entry are prone to bias if the estimation approach does not account for the endogenous determination of the underlying laws

\footnotetext{
${ }^{2}$ For a discussion of the literature on barriers to entry see Tirole (1988).

${ }^{3}$ Despite the fact that a majoritarian voting system as in the U.S. promotes the existence of two dominating political parties (Duverger, 1964), third party as well as independent candidates frequently appear on the ballot in state as well as federal elections. During the period considered in our analysis (1952 to 1984), around $17.2 \%$ of the races in U.S. House elections saw three candidates, and an additional $8.7 \%$ had four or more candidates.
} 
and regulations. The aim of this contribution is to overcome the endogeneity problem and to provide reliable evidence on the effectiveness of ballot access requirements. In doing so, our work builds on recent contributions by Aghion, Alesina, and Trebbi (2004) and Trebbi, Aghion, and Alesina (2007) which challenge the traditional view that political institutions like ballot access rules can be treated as being exogenously given.

To solve the endogeneity problem, our identification strategy exploits variation in the restrictiveness of ballot access regulations that comes from a natural experiment. In particular, we make use of the U.S. Supreme Court's decision in Williams v. Rhodes from 1968 which struck down the highly stringent ballot access laws the state of Ohio had enacted in 1951. The resulting sharp decrease in Ohio's signature requirements allows us to identify the impact of ballot access restrictions on the entry decisions of third party and independent candidates. Using electoral districts in other states with stable ballot access regulations as a control group, we show by means of difference-in-difference estimations that the Supreme Court decision of 1968 resulted in a significant increase in the number of minor party candidates. The magnitude of our estimates of the effect of Ohio's ballot access law of 1951 can be interpreted quite generally. Between 1951 and 1968 the petition requirements for third party and independent candidates were practically insurmountable in Ohio. Due to the Supreme Court decision, Ohio had to reduce its signature requirements to a level that is comparable to the moderate regulations existent in most other states. Thus, our difference-in-difference estimations quantify the potential increase in electoral competition if ballot access restrictions were lowered to moderate levels in the remaining states which practically exclude minor party candidates until today. ${ }^{4}$

Our work is related to a number of earlier contributions. Abramson and Aldrich (1995) and Rosenstone, Behr, and Lazarus (1996), for example, study the relevance of third party and independent candidates in the history of U.S. presidential elections. Amorim Neto and Cox (1997) discuss the determinants of the number of parties in general and explain it as an outcome of the interaction between the electoral system and the heterogeneity of the society.

\footnotetext{
${ }^{4}$ Georgia, for instance, still requires minor party congressional candidates to file petitions, separately for each congressional district, signed by 5 percent of registered voters eligible to vote in the last election. In order to place its candidates on the ballot in all Georgia districts, a new party would thus have to collect almost 200,000 signatures.
} 
One of the first contributions which discusses entry barriers in politics and how electoral competition can be encouraged by rising the rewards of office is Tullock (1965). Moreover, there is a small number of empirical studies analyzing the effectiveness of ballot access laws in deterring minor party candidates. Ansolabehere and Gerber (1996) find that higher filling fees increase the frequency of uncontested seats and decrease the frequency of retirements significantly when examining congressional election results from 1984 to 1990. In the same vein, Stratmann (2005) examines the effect of filling fees and signature requirements on the number of candidates in U.S. Lower House elections at the state level in 1998 and 2000. His findings also suggest that higher filling fees reduce both the number of major-party and minor-party candidates. Our analysis differs from these contributions by explicitly addressing ballot access regulations as being endogenous to the degree of electoral competition.

The paper is organized as follows. Section 2 provides the historical background of Ohio's ballot access laws. The empirical approach and the data are discussed in Section 3. Thereafter, Section 4 presents our results, and Section 5 concludes.

\section{The history of ballot access in Ohio}

The establishment of election rules was left to the states in the U.S. Constitution of 1788 since its framers did not agree on a unitary election law for the new federal government. ${ }^{5}$ Access to the ballot remained entirely unregulated during much of the 19th century because candidates were allowed to print and distribute ballot papers themselves. As these practices resulted in polling irregularities and discouraged independent candidates due to the immense costs of providing their own ballots, the state governments gradually adopted the Australian Ballot in the 1890s which among others prescribed that ballots were to be printed and distributed by the state government (Argersinger, 1980). Consequently, an official nomination procedure for potential candidates had to be established. These ballot access requirements became increasingly more complex and more stringent in the course of the 20th century. Since ballot access requirements are set by the state legislators, the demands

\footnotetext{
${ }^{5}$ See Bott (1990) for a brief history of ballot access in the United States.
} 
vary considerably both in absolute and relative terms.

The state of Ohio introduced a particularly restrictive ballot access law in 1951. Interestingly, the circumstances of its introduction seem to substantiate the notion that the stringency of entry barriers to political markets can, in general, not be regarded as exogenously given. Before 1951, Ohio required a third-party candidate to collect the signatures of only one percent of the registered voters, and third-party candidates frequently appeared on the ballot, both in federal and in state elections. In the 1948 presidential election, Henry Wallace from the Progressive Party polled 1.3 percent of the votes, leaving the Republican candidate Harry Truman a margin of only about 7,000 votes to win the state against the Democratic candidate Thomas Dewey. To rule out the possibility that third candidates prevent a clear victory of one of the major parties, the Ohio legislature adopted a new ballot access law in 1951 which practically excluded any third party candidates (Bott, 1990). To be recognized as a political party, Ohio demanded the submission of a petition signed by 15 percent of the last gubernatorial vote, an independent candidate in a state-wide election needed a petition signed by 7 percent of the last gubernatorial vote, and independent presidential candidates were not permitted. As a consequence, only the two major parties, which had to satisfy less strict requirements, were present in Ohio's political arena in the following years. Unsatisfied with their exclusion several minor parties challenged the Ohio ballot access laws by appealing to the U.S. Supreme Court. In October 1968 the Supreme Court ruled in Williams v. Rhodes that Ohio's regulations violated the 1st and 14th Amendments of the Constitution. In the Williams opinion, Justice Black observed that '[t]he state of Ohio in a series of election laws has made it virtually impossible for a new political party, even though it has hundreds of thousands of member, to be placed on the state ballot [... $]^{\prime}{ }^{6}$

Forced to reduce the barriers to entry for non-major party candidates, the Ohio legislature decided in October 1969 to lower the signature requirements for new parties to 7 percent and for independent candidates to 4 percent of the last gubernatorial vote. Yet even this softened regulation was declared unconstitutional by a three-judge U.S. District Court in July, 1970. Hence, the Ohio legislature took action again and adopted a new law (effective since March 1972) which reduced its requirements to 5,000 signatures for an office

\footnotetext{
${ }^{6}$ Cited in Bott (1990, p. 176).
} 
voted on statewide (including President) and one percent of the last gubernatorial vote in the respective district for congressional elections.

\section{Estimation approach and data}

The main purpose of our paper is to provide evidence of the effect of ballot access restrictions on electoral competition. As mentioned in the introduction, the identification of this effect is complicated by the apparent endogeneity of any regulation defining barriers to the entry of new political parties. We present a straightforward approach to solve the identification problem which exploits the Supreme Court decision of 1968 and the resulting significant reduction of ballot access requirements in Ohio as a natural experiment. To qualify as a natural experiment the units of observation need to be affected by a sharp and unexpected change in some key variable of interest (in our case, the restrictiveness of petition requirements for minor party and independent candidates). That the change in Ohio's ballot access laws resulting from the ruling in Williams $v$. Rhodes was sharp is undisputable. The state moved from being by far the most restrictive state in terms of petition requirements to a position that was very similar to the rules adopted in most other states. For a number of reasons the Supreme Court decision in Williams v. Rhodes can also be regarded as an unexpected event. First of all, when the Supreme Court struck down the law it had already been in place for 17 years. Secondly, Williams v. Rhodes was the first ruling against existing ballot access laws in the history of the Supreme Court. Note furthermore that in Jenness v. Fortson, a case showing remarkable similarities to Williams v. Rhodes, the Court upheld the ballot access law of the state of Georgia in $1971 .{ }^{7}$ Likewise, in a number of court cases in later years, existing ballot access regulations were confirmed. ${ }^{8}$ Thus, the behavior of the Supreme Court was not characterized by a general tendency to rule against pronouncedly restrictive state ballot access laws. Rather, Williams v. Rhodes constitutes a unique and unprecedented case in the history of U.S. ballot access laws.

Our estimation approach aims at comparing electoral competition in congres-

\footnotetext{
${ }^{7}$ Winger (2002) provides a detailed discussion of the Supreme Court's ruling in Jenness v. Fortson.

${ }^{8}$ See e.g. Winger (2002) and Bott (1990).
} 
sional districts in Ohio between 1952 and 1984 to electoral competition in a control group of congressional districts in other states. By means of differencein-difference estimations, we identify the impact of the exogenous variation in the stringency of entry barriers for third party and independent candidates induced by the Supreme Court decision of 1968. Our baseline estimation equation takes the form

$$
\# M I N O R_{i t}=\alpha(O H I O \times 1970-84)_{i t}+\beta O H I O_{i}+\tau_{t}+e_{i t},
$$

where \#MINOR $R_{i t}$ is the total number of minor party and independent candidates that were listed on the ballot in district $i$ in year $t$. OHIO $\times 1970-84$ is the interaction effect of a Ohio state dummy and a dummy for years after 1968, i.e. after the Supreme Court decision on Ohio's ballot access law. ${ }^{9}$ Moreover, $\tau_{t}$ is a year effect and $e_{i t}$ is a residual. The coefficient $\alpha$ captures the differential effect of the change in Ohio's ballot access requirements. Note that in some estimations we did not include year effects, but just a single postshock indicator for years after 1968. We also estimate specifications including a trend specific to congressional districts in Ohio to account for a possible trend in electoral competition in this state. This is potentially important as our estimations might otherwise pick up an independent state-specific trend in the estimate of $\alpha$, leading to false conclusions regarding the effectiveness of petition requirements in preventing electoral competition. ${ }^{10}$ Note furthermore that we cannot account for unobserved congressional district effects since the districts change considerably (at least) every ten years due to redistricting according to the update of population figures by the decennial census. For instance, the districts in the 1972 congressional election do not coincide in general with the districts in the 1968 or 1970 election.

In our analysis, we compare the congressional districts from Ohio with those from Illinois. The latter constitute a well-suited control group because Illinois was not affected by the treatment, but is very similar to Ohio in many respects. Illinois districts are eligible for the control group as the Supreme Court decision did only affect Ohio's ballot access law. Furthermore, Illinois

\footnotetext{
${ }^{9}$ We treat the year 1968 as belonging to the pre-shock period because presumably there was too little time for most potential new candidates to prepare and run a campaign. We present robustness checks for this assignment later on, suggesting that assigning the year 1968 to the post-shock period or dropping observations from 1968 does not seem to make a difference for the main results.

${ }^{10}$ Details on the specifications are reported in the tables showing the estimation results.
} 
Table 1: Means for social and economic characteristics of treatment and control

\begin{tabular}{lccc}
\hline Variable & Year & Ohio & Illinois \\
\hline \multirow{2}{*}{ Number of congressional districts } & 1952 & 23 & 25 \\
& 1968 & 24 & 24 \\
Total population (1,000's) & 1984 & 21 & 22 \\
& 1952 & 8299 & 8986 \\
Per capita income & 1968 & 10462 & 10907 \\
& 1984 & 10817 & 11428 \\
& 1952 & 5143 & 5775 \\
Educational attainment & 1968 & 7018 & 7680 \\
& 1984 & 8607 & 9628 \\
Urbanization & 1952 & 0.375 & 0.361 \\
& 1968 & 0.509 & 0.501 \\
& 1984 & 0.705 & 0.704 \\
& 1952 & 0.708 & 0.782 \\
\hline
\end{tabular}

Data sources: Statistical Abstract of the United States (various years). Per capita income is measured in 1980 dollars. Educational attainment refers to share of total population 25 years and over with a high school diploma or a higher degree. Urbanization is percentage of urban population as defined by the U.S. Census.

did not change its ballot access requirements between 1952 and $1984 .{ }^{11}$ This is important, as such changes would interfere with the differential impact of the Supreme Court decision on Ohio's congressional districts. Illinois' election law constantly demanded a number of signatures equal to a considerable 5 percent of the vote in the last election in the respective district in which a candidate was seeking access to the ballot. Thus, Illinois's law was similarly restrictive as Ohio's one before 1968. As Table 1 shows, Ohio and Illinois are also very alike in many other respects. First of all, both comprise a similar number of congressional districts. Ohio has between 21 and 24 districts, while Illinois has 22 to 25. Moreover, both states are demographically and economically very much alike. During the period we consider, both have almost the same population, per capita income, educational attainment and level of urbanization. Finally, Illinois is roughly of the same size and geographically close to Ohio.

Table 2 presents the summary statistics of the dependent and the key explanatory variables. The data on election outcomes for U.S. House elections between 1952 and 1984 come from the Interuniversity Consortium for Political

\footnotetext{
${ }^{11}$ We checked this by searching over the states' revised statutes for changes in ballot access laws for the whole period considered in our analysis.
} 
Table 2: Summary statistics

\begin{tabular}{lcccc}
\hline Variable & Mean & Std. Dev. & Min & Max \\
\hline Third party and independent candidates & 0.123 & 0.425 & 0 & 4 \\
OHIO & 0.488 & 0.500 & 0 & 1 \\
$1970-84$ & 0.521 & 0.499 & 0 & 1 \\
OHIO $\times 1970-84$ & 0.256 & 0.437 & 0 & 1 \\
\hline
\end{tabular}

Sample includes all electoral races for the U.S. House of Representatives from 1952 to 1984 in Ohio and Illinois (Nob=799). Sources: Interuniversity Consortium for Political and Social Research (1994), the Office of the Clerk of the U.S. House of Representatives, Winger (2006) and the revised state codes for the respective states and several years. OHIO is an indicator for the state of Ohio. OHIO $\times 1970-84$ is the interaction between OHIO and an indicator for years after 1968.

and Social Research (1994). These contain a record for each individual candidate, providing information on the candidate's name, party affiliation, and the number of votes received. From the party code we identified third party and independent candidates. In some rare cases the party codes are missing. Therefore, we checked the party affiliation of all candidates with missing party codes by referring to the official congressional election statistics. ${ }^{12}$ For our analysis we only considered third party and independent candidates that were actually listed on the ballot. Hence, we eliminated write-in candidates from our data set and ignored scattered votes. Moreover, we restrict attention to general elections. The numbers in Table 2 confirm that our sample is almost perfectly balanced between districts belonging to either treatment and control group, and observations from pre- as well as post-shock periods.

\section{Results}

Before turning to the outcomes of our difference-in-difference estimations, we will first provide an intuition for our results by a comparison of means of the number of third party and independent candidates before and after 1968. As Table 3 shows, the average number of third party and independent candidates on the ballot in Ohio jumped from virtually zero before 1968 to 0.44 on average after 1968. In Illinois, however, the increase in the number of third party and independent candidates was much less pronounced.

This difference is illustrated in more detail in Figure 1. Between 1952 and

\footnotetext{
${ }^{12}$ These statistics are available from the office of the Clerk of the U.S. House of Representatives at http://clerk.house.gov/member_info/electionInfo/index.html.
} 
Table 3: Average number of Congressional candidates per district, 1950-1968 and 1970-1984

\begin{tabular}{lccccccc}
\hline & \multicolumn{1}{c}{$1952-1968$} & \multicolumn{4}{c}{$1970-1984$} \\
& Nob & Mean & Std. Dev. & \multicolumn{1}{c}{ Nob } & Mean Std. Dev. \\
\hline OHIO & & & & & & \\
$\quad$ Overall number of candidates & 209 & 1.99 & 0.18 & 181 & 2.36 & 0.81 \\
$\quad$ Major party candidates & 209 & 1.98 & 0.14 & 181 & 1.92 & 0.27 \\
$\quad$ Third party \& independent candidates & 209 & 0.01 & 0.12 & 181 & 0.44 & 0.75 \\
ILLINOIS & & & & & & \\
$\quad$ Overall number of candidates & 221 & 2.00 & 0.12 & 188 & 2.05 & 0.31 \\
$\quad$ Major party candidates & 221 & 1.99 & 0.07 & 188 & 1.97 & 0.16 \\
$\quad$ Third party \& independent candidates & 221 & 0.01 & 0.09 & 188 & 0.08 & 0.29 \\
\hline
\end{tabular}

Sample: Congressional districts of Ohio and Illinois in Congressional election years from 1952 to 1984. Total number of observations $=799$.

1968, in both states the number of third party and independent candidates was close to zero. While Illinois experienced a moderate increase beginning in 1972, the average number of third party and independent candidates in Ohio quickly soared to more than 0.8 in 1976. This number went down to values around 0.3 in 1978/80 and raised again to a value somewhat below 0.8 in 1982. In all years beginning with 1970, the number of third party and independent candidates in Ohio was higher than in Illinois. The numbers in Table 3 and the graph in Figure 1 give a first impression of the effectiveness of Ohio's ballot access laws before 1968. The evidence suggests that the Supreme Court decision had a strong and immediate impact on electoral competition. However, we need a more technical approach to substantiate the descriptive evidence. In particular, we would like to check the statistical significance of the effects suggested by the descriptive analysis.

We now turn to the results of our difference-in-difference estimation approach. Table 4 displays a first set of results. The dependent variable is the number of third party and independent candidates. Our units of observation are 799 electoral races for the U.S. House of Representatives in Ohio and Illinois between 1952 and 1984.

Column (1) shows the results for a baseline specification of our difference-indifference model. Besides the interaction term Ohio $\times(1970-84)$, it accounts only for an Ohio state effect and the indictor for the post-shock period. The increase in the number of third party and independent candidates in Ohio (relative to congressional districts in Illinois) resulting from the Supreme Court 
Figure 1: Average number of third party and independent candidates per district in U.S. House elections, 1950-1984

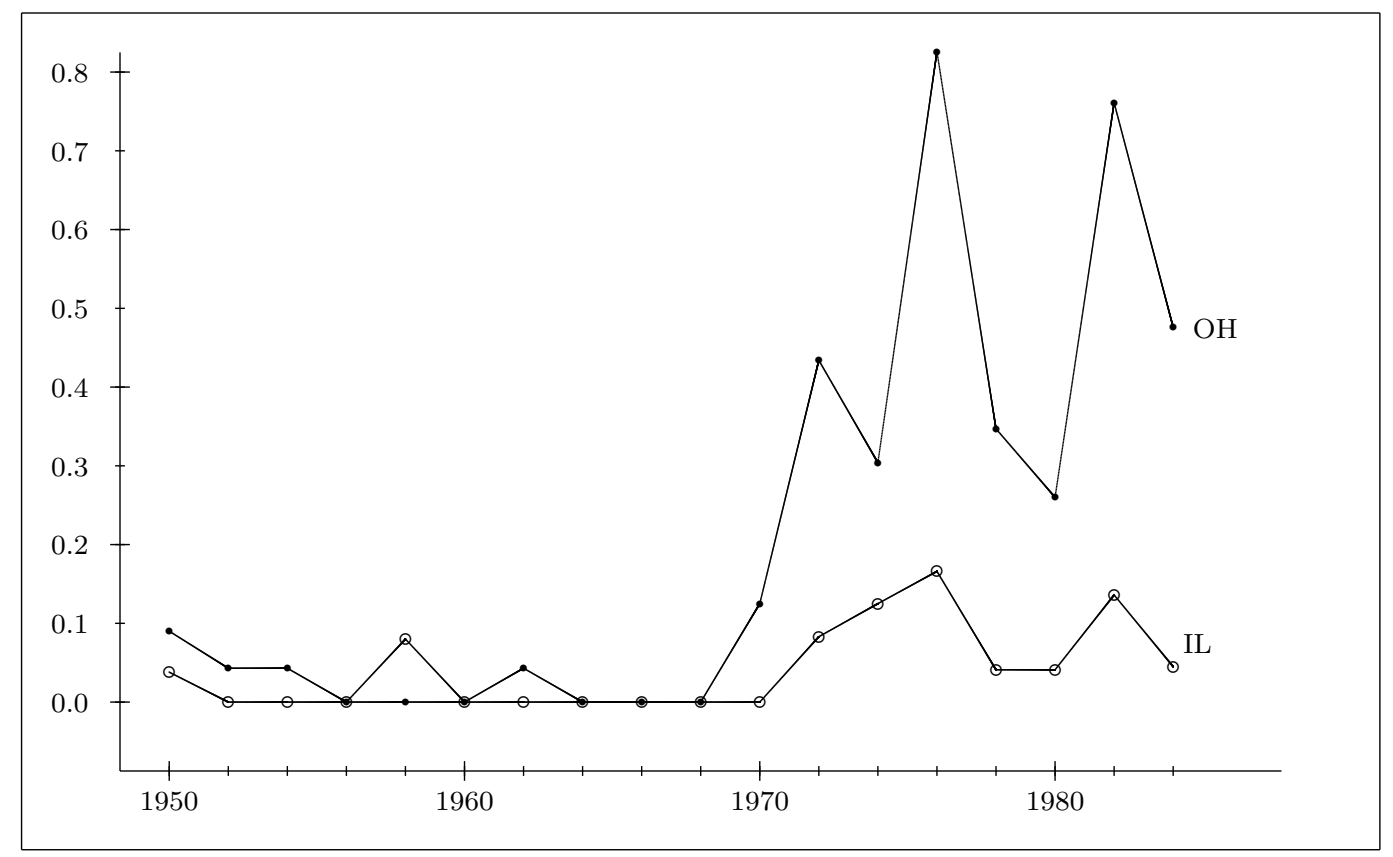

decision is estimated to be 0.25 and is significant at the $1 \%$ level. The magnitude of the treatment effect is notable (recall that the average number of minor party candidates is only 0.12 in our sample). Note that we report standard errors that account for clustering on congressional districts. Since districts boundaries change regularly due to redistricting, we form district-specific clusters for the periods 1952-1960, 1962-1970, 1972-1980, and 1982-1984. This gives 186 clusters for the sample with 799 observations.

In Column (2) we replace the indicator for post-shock periods by a full series of year effects. The results of the baseline specification do not change qualitatively. In fact, the estimate for the treatment effect increases to 0.31 and remains highly significant. In Column (3) we split the single treatment effect employed in the first two specifications into a full series of interaction effects, giving a separate treatment effect for each post-shock year. Column (3) thus gives a much more detailed picture of the effects of the change in ballot access on the entry of third party and independent candidates. We note that the estimates for all year-specific treatment effects are positive, with five out of eight estimated coefficients being statistically different from zero at least at the $5 \%$ level. The size of the treatment effect varies between 0.30 in 1978 and 
Table 4: Ballot access and electoral competition in U.S. House elections, difference-indifference estimations based on Ohio and Illinois

\begin{tabular}{|c|c|c|c|c|c|c|c|}
\hline Dependent varia & $\begin{array}{l}\text { Number } \\
(1)\end{array}$ & $\begin{array}{l}\text { third part } \\
\text { (2) }\end{array}$ & $\begin{array}{c}\text { and indepe } \\
\text { (3) }\end{array}$ & $\begin{array}{l}\text { lent candi } \\
\text { (4) }\end{array}$ & (5) & (6) & $(7)$ \\
\hline Ohio & $\begin{array}{c}0.036^{\star \star} \\
(0.015)\end{array}$ & $\begin{array}{c}0.006 \\
(0.014)\end{array}$ & $\begin{array}{c}0.005 \\
(0.012)\end{array}$ & $\begin{array}{c}0.029 \\
(0.051)\end{array}$ & $\begin{array}{c}0.034 \\
(0.058)\end{array}$ & $\begin{array}{c}0.048^{\star \star \star} \\
(0.015)\end{array}$ & $\begin{array}{c}0.051 \\
(0.052)\end{array}$ \\
\hline 1970-1984 & $\begin{array}{c}0.133^{\star \star \star} \\
(0.024)\end{array}$ & - & - & - & - & $\begin{array}{c}0.179^{\star \star \star} \\
(0.035)\end{array}$ & - \\
\hline Ohio time trend & - & - & - & $\begin{array}{l}-0.003 \\
(0.005)\end{array}$ & $\begin{array}{l}-0.003 \\
(0.006)\end{array}$ & - & $\begin{array}{l}-0.004 \\
(0.004)\end{array}$ \\
\hline Ohio $\times(1970-84)$ & $\begin{array}{c}0.250^{\star \star \star} \\
(0.054)\end{array}$ & $\begin{array}{c}0.310^{\star \star \star} \\
(0.061)\end{array}$ & - & - & - & $\begin{array}{c}0.180^{\star \star \star} \\
(0.057)\end{array}$ & - \\
\hline Ohio $\times 1970$ & - & - & $\begin{array}{c}0.119 \\
(0.070)\end{array}$ & $\begin{array}{l}0.134^{\star} \\
(0.071)\end{array}$ & $\begin{array}{l}0.139^{\star} \\
(0.075)\end{array}$ & - & $\begin{array}{l}0.129^{\star} \\
(0.069)\end{array}$ \\
\hline Ohio $\times 1972$ & - & - & $\begin{array}{c}0.345^{\star \star} \\
(0.162)\end{array}$ & $\begin{array}{c}0.364^{\star \star} \\
(0.163)\end{array}$ & $\begin{array}{c}0.369^{\star \star} \\
(0.165)\end{array}$ & - & $\begin{array}{c}0.360^{\star \star} \\
(0.162)\end{array}$ \\
\hline Ohio $\times 1974$ & - & - & $\begin{array}{c}0.173 \\
(0.194)\end{array}$ & $\begin{array}{c}0.195 \\
(0.196)\end{array}$ & $\begin{array}{c}0.201 \\
(0.198)\end{array}$ & - & $\begin{array}{c}0.192 \\
(0.195)\end{array}$ \\
\hline Ohio $\times 1976$ & - & - & $\begin{array}{c}0.653^{\star \star \star} \\
(0.199)\end{array}$ & $\begin{array}{c}0.678^{\star \star \star} \\
(0.201)\end{array}$ & $\begin{array}{c}0.685^{\star \star \star} \\
(0.204)\end{array}$ & - & $\begin{array}{c}0.677^{\star \star \star} \\
(0.200)\end{array}$ \\
\hline Ohio $\times 1978$ & - & - & $\begin{array}{c}0.300^{\star \star} \\
(0.141)\end{array}$ & $\begin{array}{c}0.327^{\star \star} \\
(0.145)\end{array}$ & $\begin{array}{c}0.335^{\star \star} \\
(0.150)\end{array}$ & - & - \\
\hline Ohio $\times 1980$ & - & - & $\begin{array}{c}0.213 \\
(0.135)\end{array}$ & $\begin{array}{l}0.243^{\star} \\
(0.141)\end{array}$ & $\begin{array}{l}0.252^{\star} \\
(0.147)\end{array}$ & - & - \\
\hline Ohio $\times 1982$ & - & - & $\begin{array}{c}0.620^{\star \star \star} \\
(0.207)\end{array}$ & $\begin{array}{c}0.653^{\star \star \star} \\
(0.212)\end{array}$ & $\begin{array}{c}0.662^{\star \star \star} \\
(0.216)\end{array}$ & - & - \\
\hline Ohio $\times 1984$ & - & - & $\begin{array}{c}0.425^{\star \star} \\
(0.169) \\
\end{array}$ & $\begin{array}{c}0.461^{\star \star \star} \\
(0.177)\end{array}$ & $\begin{array}{c}0.471^{\star \star \star} \\
(0.183) \\
\end{array}$ & - & - \\
\hline$\overline{\text { Years }}$ & $1952-84$ & $1952-84$ & $1952-84$ & $1952-84$ & $1952-84^{a}$ & $1960-76$ & $1960-76$ \\
\hline Nob & 799 & 799 & 799 & 799 & 751 & 427 & 427 \\
\hline Year effects & No & Yes & Yes & Yes & Yes & No & Yes \\
\hline
\end{tabular}

\subsection{5 in 1976.}

As mentioned above, the difference-in-difference approach is generally prone to bias in the estimate of the treatment effect in the presence of a treatmentgroup specific trend which is not properly accounted for in the model. To hedge against such a potential bias, we allow for a time trend specific to districts in Ohio. As the results reported in Column (4) show, the coefficient of the trend itself is not statistically different from zero, and the general picture regarding the treatment effects is unchanged. Note, however, that now seven out of eight year-specific treatment effects are estimated to be statistically different from zero at least at the $10 \%$ level.

So far we have presented results with observations from the year 1968, i.e. the year of the Supreme Court decision, assigned to the pre-shock period. In order to check the robustness of our findings with respect to this assignment, we 
excluded these observations and re-estimated the model with the full series of year-specific treatment effects and including the Ohio time trend. The results, displayed in Column (5), are almost identical to those obtained with observations from 1968 assigned to the pre-shock period. We conclude that the assignment of these observations does not critically affect our results.

A well-known further criticism of difference-in-difference estimations is that with many time periods in the sample and significantly serially correlated observations, the approach may overstate the true effects. To account for this objection, we re-estimated both the baseline specification (Column (6)) and the model with a full series of year effects, the Ohio time trend and year-specific treatment effects (Column (7)) using only observations from the period 1960-1976. This reduces the number of observations to 427. Again, our results prove to be highly robust. In particular, the coefficient estimates of the year-specific treatment effects in Column (7) are very close to their counterparts in Column (6).

The bottom line from the series of difference-in-difference estimations reported in Table 4 is that the preliminary findings from the descriptive analysis are confirmed. In particular, we note that the strong effect of the Supreme Court decision on electoral competition is statistically significant and robust to various and substantial changes in specification.

A potential objection to our identification approach might be the low variation in the number of third party and independent candidates in Illinois. Based on the descriptive evidence reported in Table 3 and Figure 1, one could argue that our approach comes close to comparing the variation in the number of candidates in the treatment districts to a variable which is constant over time in most districts belonging to the control group. In that case the difference-in-difference approach could be misleading, as the variation in electoral competition in Illinois might simply be suppressed by the very special circumstances of this particular state, namely its highly restrictive ballot access laws. To address this point, we extend our analysis by expanding the control group by further congressional districts from three additional states: Indiana, Kentucky and New Jersey. We selected these states based on two criteria: Firstly, we can only make use of districts from states that did not change their ballot access laws during at least a substantial part of the time 
Table 5: Average number of congressional candidates per district, 1952-1968 and 1970-1984

\begin{tabular}{lcccccc}
\hline & \multicolumn{3}{c}{$1952-1968$} & \multicolumn{5}{c}{$1970-1984$} \\
& Nob & Mean & Std. Dev. & Nob & Mean Std. Dev. \\
\hline IL, IN, KY \& NJ & & & & & & \\
$\quad$ Overall number of candidates & 518 & 2.35 & 0.83 & 400 & 2.53 & 0.99 \\
$\quad$ Major party candidates & 518 & 1.96 & 0.17 & 400 & 1.98 & 0.15 \\
$\quad$ Third party \& independent candidates & 518 & 0.38 & 0.80 & 400 & 0.55 & 0.98 \\
\hline
\end{tabular}

Sample includes electoral races for the U.S. House of Representatives from Ohio (1952-1984), Illinois (19521984), Indiana (1952-1980), Kentucky (1952-1976) and New Jersey (1952-1984).

period under consideration. Secondly, the ballot access laws of the additional states should be significantly less restrictive than those in Illinois in order to induce more substantial variation in electoral competition within the control group.

Table 5 displays descriptive statistics of electoral competition as measured by the number of minor party candidates within the extended control group. A quick inspection reveals that the number of third party and independent candidates now exhibits substantial variation both before and after 1968 . Difference-in-difference estimations based on the extended sample should therefore provide us with a valid point of reference for the results discussed above. Note that we cannot employ all observations in the respective sample since Indiana and Kentucky altered their ballot access rules towards the end of the period considered. We therefore restrict our attention to the period from 1952 to 1976 .

The results based on the extended sample are reported in Table 6. Column (1) again shows the baseline specification including a full series of state dummies, while Column (2) repeats the estimation with a full series of year effects instead of a single indicator for post-shock-periods. We obtain highly significant estimates of the treatment effect in both cases, with slightly lower point estimates compared to the estimations with only districts from Illinois forming the control group. Following the example of the results presented in Table 4, Column (3) replaces the single treatment effect by year specific interactions. Again, we find all estimated parameters to be positive, and three out of five effects are significant at least at the $5 \%$ level. Finally, Column (4) demonstrates that adding a time trend specific to districts in Ohio does nothing to our main results. 
Table 6: Ballot access and electoral competition in U.S. House elections, difference-indifference estimations based on districts in Ohio, Illinois, Indiana, Kentucky and New Jersey

\begin{tabular}{|c|c|c|c|c|}
\hline \multicolumn{4}{|c|}{ Dependent variable: Number of third party and independent candidates } & $(4)$ \\
\hline \multirow[t]{2}{*}{ Ohio } & $-1.19^{\star \star \star}$ & $-1.20^{\star \star \star}$ & $-1.21^{\star \star \star}$ & $-1.26^{\star \star \star}$ \\
\hline & $(0.104)$ & $(0.107)$ & $(0.105)$ & $(0.166)$ \\
\hline \multirow[t]{2}{*}{ Illinois } & $-1.21 \star \star \star$ & $-1.21 \star \star \star$ & $-1.22^{\star \star \star}$ & $-1.21 \star \star \star$ \\
\hline & $(0.105)$ & $(0.105)$ & $(0.105)$ & $(0.105)$ \\
\hline \multirow[t]{2}{*}{ Indiana } & $-0.950 \star \star \star$ & $-0.951^{\star \star \star}$ & $-0.951 \star \star \star$ & $-0.952^{\star \star \star}$ \\
\hline & $(0.120)$ & $(0.117)$ & $(0.117)$ & $(0.117)$ \\
\hline \multirow[t]{2}{*}{ Kentucky } & $-1.05^{\star \star \star}$ & $-1.05^{\star \star \star}$ & $-1.05^{\star \star \star}$ & $-1.05^{\star \star \star}$ \\
\hline & $(0.117)$ & $(0.115)$ & $(0.116)$ & $(0.116)$ \\
\hline \multirow[t]{2}{*}{ 1970-1984 } & $0.122^{\star}$ & - & - & - \\
\hline & $(0.063)$ & & & \\
\hline \multirow[t]{2}{*}{ Ohio time trend } & - & - & - & 0.006 \\
\hline & & & & $(0.012)$ \\
\hline \multirow[t]{2}{*}{ Ohio $\times(1970-76)$} & $0.219^{\star \star \star}$ & $0.228^{\star \star \star}$ & - & - \\
\hline & $(0.078)$ & $(0.087)$ & & \\
\hline \multirow[t]{2}{*}{ Ohio $\times 1970$} & - & - & $0.317^{\star \star \star}$ & $0.284^{\star \star \star}$ \\
\hline & & & $(0.099)$ & $(0.110)$ \\
\hline \multirow[t]{2}{*}{ Ohio $\times 1972$} & - & - & $0.486^{\star \star \star}$ & $0.446^{\star \star}$ \\
\hline & & & $(0.177)$ & $(0.188)$ \\
\hline \multirow[t]{2}{*}{ Ohio $\times 1974$} & - & - & 0.058 & 0.011 \\
\hline & & & $(0.217)$ & $(0.229)$ \\
\hline \multirow[t]{2}{*}{ Ohio $\times 1976$} & - & - & $0.421^{\star \star}$ & 0.368 \\
\hline & & & $(0.213)$ & $(0.231)$ \\
\hline Years & $1952-76$ & $1952-76$ & $1952-76$ & $1952-76$ \\
\hline Nob & 1048 & 1048 & 1048 & 1048 \\
\hline Year effects & No & Yes & Yes & Yes \\
\hline
\end{tabular}

We conclude that adding congressional districts from three additional states to extend the control group and to induce higher variation in electoral competition within this subsample confirms the results derived from estimations where the control group comprises only districts from Illinois.

\section{Conclusion}

This paper investigates the effect of barriers to entry on electoral competition. In particular, we provide evidence on the impact of ballot access restrictions on entry decisions of third party and independent candidates. We note that earlier studies have failed to take account of the potential endogeneity of ballot access requirements. Taking seriously recent contributions by Aghion, Alesina, and Trebbi (2004) and Trebbi, Aghion, and Alesina (2007) claiming that political institutions should generally be treated as endogenous, we suggest an 
identification approach that exploits exogenous variation in the stringency of ballot access requirements. The identification rests on the idea to utilize the U.S. Supreme Court decision of 1968 to struck down Ohio's ballot access law and the resulting sharp decrease in signature requirements for third party and independent candidates in Ohio as a natural experiment. By means of difference-in-difference estimations using observations from electoral races in U.S. House elections from 1952 to 1984, we identify the effectiveness of ballot access restrictions in deterring electoral competition.

Our results indicate that ballot access requirements as used in most U.S. states can be highly effective in reducing the degree of electoral competition faced by major party candidates. This finding, in turn, suggests to take serious the potential endogeneity of political institutions, in particular in cases where it is plausible to assume that stakes of powerful players in the political arena are directly affected by the design of certain institutions. Hence, the empirical evidence presented in this study strongly suggests to understand political institutions as being subject to strategic choice of influential actors such as governments and legislatures.

\section{Acknowledgements}

We would like to thank Thomas Stratmann and seminar participants at the University of Munich for useful comments and Richard Winger for generously sharing with us his knowledge on U.S. ballot access laws.

\section{References}

Abramson, P. R., And J. H. Aldrich (1995): "Third party and independent candidates in American politics: Wallace, Anderson and Perot," Political Science Quarterly, 110, 349-368.

Aghion, P., A. Alesina, And F. TrebBi (2004): "Endogenous political institutions," Quarterly Journal of Economics, 119, 565-611.

Amorim Neto, O., And G. W. Cox (1997): "Electoral institutions, cleavage structures, and the number of parties," American Journal of Political Science, 41(1), 149-174. 
Ansolabehere, S., And A. Gerber (1996): "The effects of filling fees and petition requirements on U.S. House elections," Legislative Studies Quarterly, 21, 149-164.

Argersinger, P. H. (1980): "A place on the ballot: Fusion politics and antifusion laws," The American Historical Review, 85(2), 287-306.

Botт, A. J. (1990): Handbook of United States election laws and practices. Greenwood Press, Westport.

Duverger, M. (1964): Les partis politiques. Colin, Paris.

Interuniversity Consortium for Political and Social Research (1994): Candidate and constituency statistics of elections in the United States, 1788-1990. Ann Arbor, Michigan.

Persson, T., and G. Tabellini (2000): Political economics: Explaining economic policy. The MIT Press, Cambridge (Mass.).

Rosenstone, S. J., R. L. Behr, and E. H. Lazarus (1996): Third parties in America. Princeton University Press.

Stratmann, T. (2005): "Ballot access restrictions and candidate entry in elections," European Journal of Political Economy, 21, 59-71.

Tirole, J. (1988): Industrial organisation. Cambridge University Press.

Trebbi, F., P. Aghion, And A. Alesina (2007): "Electoral rules and minority representation," Mimeo, Harvard University.

Tullock, G. (1965): "Entry barriers in politics," American Economic Review, 55(1), 458-466.

Winger, R. (2002): "The Supreme Court and the burial of ballot access: A critical review of Jenness v. Fortson," Election Law Journal, 1(2), 235-252. 